\title{
Detection of anti-Toxoplasma gondiiantibodies in wild free-living birds and mammals from the northwest region of São Paulo state, Brazil
}

\author{
Deteç̧ão de anticorpos anti-Toxoplasma gondii em aves e mamíferos \\ silvestres de vida livre da região noroeste do estado de São Paulo, Brasil
}

\begin{abstract}
Lilian Castiglioni ${ }^{1,2,3 *}$ (D); Luiz Paulo Nogueira Aires ${ }^{2}$; Vinícius Matheus Ferrari ${ }^{4}$; Fernando Henrique Antunes Murata ${ }^{3}$, Herbert Sousa Soares 5 ; Solange Maria Gennari ${ }^{5}$; Juliana Giantomassi Machado²; Adriana Santiago Fracischetti²; Ricardo Quitério Sartori ${ }^{4}$, Luiz Carlos de Mattos ${ }^{3}$; Cinara Cássia Brandão ${ }^{3}$; Hilda Fátima Jesus Pena ${ }^{5}$

${ }^{1}$ Faculdade de Medicina de São José do Rio Preto, Departamento de Epidemiologia e Saúde Coletiva, São José do Rio Preto - SP, Brazil ${ }^{2}$ Centro Universitário de Rio Preto, São José do Rio Preto - SP, Brazil

${ }^{3}$ Faculdade de Medicina de São José do Rio Preto, Departamento de Biologia Molecular, FAMERP Toxoplasma Research Group, São José do Rio Preto - SP, Brazil

${ }^{4}$ Universidade Estadual Paulista "Júlio de Mesquita” Filho, Instituto de Biociências, Letras e Ciências Exatas, São José do Rio Preto - SP, Brazil

${ }^{5}$ Universidade de São Paulo, Faculdade de Medicina Veterinária e Zootecnia, Departamento de Medicina Veterinária Preventiva e Saúde Animal, Laboratório de Doenças Parasitárias, São Paulo - SP, Brazil
\end{abstract}

\begin{abstract}
Toxoplasmosis is a protozoonosis caused by an obligate intracellular parasite named Toxoplasma gondii, which can infect humans and a large number of homeothermic animal species with worldwide distribution. The present study aimed to detect anti-T. gondii antibodies from serological samples of free-living wild animals from the northwest region of São Paulo state, Brazil. Thirty-two samples (eight from birds and 24 from mammals) were analyzed by the modified agglutination test (MAT) using 5 cut-off points for birds and 25 for mammals. Seropositivity was observed in 25\% (2/8) of birds, including the species Rupornis magnirostris (roadside hawk) and Caracara plancus (southern caracara), and 29.2\% (7/24) animals were seropositive among mammals, including one hoary fox (Lycalopex vetulus), two maned wolves (Chrysocyon brachyurus), one black howler monkey (Alouatta caraya), two crab-eating foxes (Cerdocyon thous) and one gray brocket deer (Mazama gouazoubira). The results obtained with the present study indicate the exposure to T. gondii of free-living wild animals from the northwest region of São Paulo state and, therefore, that they probably play a role in the transmission and maintenance of T. gondii in the environment they inhabit. Thus, identification of the infection in several animal species in the region indicates the environmental contamination of the area. Studies of this nature may help to understand the importance of the prevention and control of this disease in Brazil.
\end{abstract}

Keywords: Toxoplasmosis. MAT. Wildlife. Zoonosis. Serology. Occurrence.

\section{RESUMO}

A toxoplasmose é uma protozoonose causada por um parasita intracelular obrigatório denominado Toxoplasma gondii, que pode infectar os humanos e um vasto número de espécies animais homeotérmicas, apresentando distribuição mundial. O presente estudo objetivou a detecção de anticorpos anti-T. gondii a partir de amostras sorológicas de animais silvestres de vida livre da região noroeste do estado de São Paulo. Foram analisadas 32 amostras (oito de aves e 24 de mamíferos) por meio do teste de aglutinação modificado (MAT), utilizando ponto de corte 5 para as aves e 25 para os mamíferos. Soropositividade foi observada em 25\% (2/8) das aves, incluindo as espécies Rupornis magnirostris (gavião-carijó) e Caracara plancus (carcará); entre os mamíferos, 29,2\% (7/24) foram soropositivos incluindo uma raposa-do-campo (Lycalopex vetulus), dois lobos-guará (Chrysocyon brachyurus), um bugio-preto (Alouatta caraya), dois cachorros-do-mato (Cerdocyon thous) e um veado-catingueiro (Mazama gouazoubira). Os resultados obtidos com o presente estudo indicam a exposição dos animais selvagens de vida livre a T. gondii na região noroeste do estado de São Paulo e, portanto, que provavelmente apresentam papel na transmissão e manutenção de T. gondii no meio ambiente em que vivem. Assim, a identificação da infecção em várias espécies de animais na região indica a contaminação ambiental da área. Estudos dessa natureza podem ajudar no entendimento sobre a prevenção e o controle dessa importante doença no Brasil.

Palavras-chave: Toxoplasmose. Teste de aglutinação. Animais selvagens. Zoonose. Sorologia. Ocorrência. 
Correspondence to:

Lilian Castiglioni

Faculdade de Medicina de São José do Rio Preto,

Departamento de Epidemiologia e Saúde Coletiva

Av. Brigadeiro Faria Lima, 5416, Vila São Pedro

CEP: 15090-000, São José do Rio Preto - SP, Brazil

e-mail: clilian@terra.com.br

Received: October 26, 2020

Approved: June 23, 2021

How to cite: Castiglioni L, Aires LPN, Ferrari VM, Murata FHA, Soares HS, Gennari SM, Machado JG, Fracischetti AS, Sartori RQ, Mattos LC, Brandão CC, Pena HFJ. Detection of anti-Toxoplasma gondii antibodies in wild free-living birds and mammals from the northwest region of São Paulo state, Brazil. Braz J Vet Res Anim Sci. 2021;58:e176683. https://doi.org/10.11606/issn.1678-4456. bjvras.2021.176683

Toxoplasma gondii is a protozoan that has a wide geographical distribution in Brazil and the world and is capable of infecting humans and other homeothermic animals, both domestic and wild. This parasite has a heteroxenous life cycle and felids are the definitive hosts, playing a key role as they are the only ones that can excrete fecal oocysts. Transmission can occur by ingestion of infective oocysts in soil, water, and food, by ingestion of cysts containing bradyzoites (carnivorism) and, congenitally, by the transplacental transmission of tachyzoites (Dubey et al., 1995; Dubey, 2010; Weiss \& Dubey, 2009).

Several studies show variation in T. gondii seroprevalence in different animal species (from 23 to $83 \%$, up to $90 \%$ ) and these differences may be associated with geographic, climatic, cultural, and socioeconomic factors (Dubey et al., 2012; Fialho et al., 2009; Gennari et al., 2004; Minervino et al., 2010; Vitaliano et al., 2014).
This type of study is relevant because it contributes to an indication of the environmental contamination and the dimension of the toxoplasmosis problem in a region, as well as the participation of the hosts in the maintenance of the life cycle.

The present study aimed to detect the presence of anti-T. gondii antibodies in different species of wild freeliving birds and mammals in the northwest region of the state of São Paulo, Brazil.

The study area was the northwest region of the state of São Paulo, Brazil, in a perimeter of approximately $150 \mathrm{~km}$ around the municipality of São José do Rio Preto

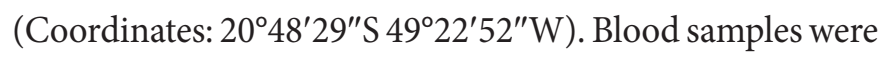
obtained from six species of wild birds (eight samples) and nine species of wild mammals (24 samples), in a total of 32 samples (Table 1).

All included animals were rescued by the State Environmental Police and the Federal Highway Police after being run over or injured because of burnings that are common in the region due to the planting of some crops, such as sugar cane. It was not possible to get data on the exact location where the animals were rescued. These injured animals were referred to a veterinary hospital where first aid and clinical conduct were provided. The responsible veterinarian collected blood for emergency animal examinations and the unused blood volume was made available for the development of this study.

Serum samples were tested using the modified agglutination test (MAT) to detect antibodies against T. gondii (Dubey \& Desmonts, 1987). The cut-off used for the serological test was 25 for mammals (Dubey, 1997) and 5 for birds (Dubey et al., 2016). All positive samples were two-fold serially diluted for titration.

The frequency of occurrence of antibodies against T. gondii observed in free-living birds and mammals from the northwest region of the state of São Paulo are summarized

Table 1. Anti-Toxoplasma gondii antibodies in free-living wild birds from the northwest region of São Paulo state, Brazil, using the modified agglutination test (MAT $\geq 5)$

\begin{tabular}{|c|c|c|c|c|}
\hline Species & N. negative & N. positive & Total & MAT titers \\
\hline \multicolumn{5}{|l|}{ Accipitriformes } \\
\hline Rupornis magnirostris & 1 & 1 & 2 & 120 \\
\hline \multicolumn{5}{|l|}{ Falconiformes } \\
\hline Caracara plancus & 0 & 1 & 1 & 20 \\
\hline \multicolumn{5}{|l|}{ Cathartiformes } \\
\hline Coragyps atratus & 1 & 0 & 1 & $<5$ \\
\hline \multicolumn{5}{|l|}{ Cariamiformes } \\
\hline Cariama cristata & 2 & 0 & 2 & $<5$ \\
\hline \multicolumn{5}{|l|}{ Pelecaniformes } \\
\hline Tigrisoma lineatum & 1 & 0 & 1 & $<5$ \\
\hline Nycticorax nycticorax & 1 & 0 & 1 & $<5$ \\
\hline
\end{tabular}


in Tables 1 and 2, respectively. Seropositivity was observed in 25\% (2/8) of birds, including Rupornis magnirostris (roadside hawk) and Caracara plancus (southern caracara) species. Among mammals, 29.2\% (7/24) were seropositive including Lycalopex vetulus (hoary fox), Chrysocyon brachyurus (maned wolf), Alouatta caraya (black howler monkey), Cerdocyon thous (crab-eating fox), and Mazama gouazoubira (gray brocket deer) species. No statistical analysis was performed due to the limited number and convenience of the samples.

Serological evidence of contact with T. gondii had previously been reported in free-living animals of the C. plancus, M. gouazoubira, and L. vetulus species in the study by Vitaliano et al. (2014); in A. caraya and C. thous by Da Silva et al. (2014), and C. brachyurus by Vitaliano et al. (2014), Da Silva et al. (2014), and Oliveira et al. (2016), also in the state of São Paulo, highlighting the circulation of the agent in the state. For the first time, in the northwest region of the state of São Paulo, the presence of anti-T. gondii antibodies are reported in $R$. magnirostris. Isolation of $T$. gondii in this bird of prey species has been reported in Minas Gerais state (Rêgo et al., 2018). Gonçalves et al. (2013) had already reported the presence of T. gondii in this species, although it was in the central west region of the state of São Paulo.

The fact that the birds of prey species were seropositive is probably because they preyed on infected animals, and carnivorous species may have become infected by ingesting prey tissues.

These results are important because the northwest region of the state of São Paulo is a major producer of poultry products and wild fauna can contribute to the maintenance of diseases for poultry (Gonçalves et al., 2013).
Thus, monitoring the health of wild birds and mammals can contribute to the assessment of the presence of diseases of economic interest. Still, according to Gonçalves et al. (2013), in the case of carnivorous birds, because they feed on previously contaminated prey (through indirect contact), they serve as "sentinel" birds with great potential for an epidemiological reading of the studied disease.

Concerning non-reactive bird species such as Coragyps atratus, Cariama cristata, and Nycticorax nycticorax, the eating habits could contribute to infection by T. gondii, but the small number of samples did not allow for a more detailed analysis. This fact could be emphasized by other studies that identified T. gondii infection in the aforementioned species (Chen et al., 2015; Gennari et al., 2017; Vitaliano et al., 2014).

Regarding the seropositive mammals, the reactive specimens are carnivorous or predator species, except for A. caraya and M. gouazoubira.

In the case of the A. caraya species, because it is an arboreal species but has a foraging habit and feeds mainly on shoots and leaves, its infection may be attributed to environmental contamination, probably by oocysts released into the environment by infected felids. The species (A. caraya) has already been reported to be infected by T. gondii (Garcia et al., 2005).

Furthermore, the species M. gouazoubira is a terrestrial species and is considered predisposed to T. gondii infection, since the prevalence of $T$. gondii for terrestrial species was shown to be significantly higher than for arboreal animals. Also, the feeding habits of the species suggest a propensity to infection with T. gondii oocysts found in the environment, which are excreted from wild felids and may contaminate water sources and wash up on stream banks,

Table 2. Anti-Toxoplasma gondii antibodies in free-living wild mammals from the northwest region of São Paulo state, Brazil, using the modified agglutination test (MAT $\geq 25)$

\begin{tabular}{|c|c|c|c|c|}
\hline Species & N. negative & N. positive & Total & MAT titers \\
\hline \multicolumn{5}{|l|}{ Carnivora } \\
\hline Lycalopex vetulus & 1 & 1 & 2 & 200 \\
\hline Chrysocyon brachyurus & 1 & 2 & 3 & 50,100 \\
\hline Cerdocyon thous & 2 & 2 & 4 & 200,1600 \\
\hline \multicolumn{5}{|l|}{ Primates } \\
\hline Alouatta caraya & 3 & 1 & 4 & 25 \\
\hline Sapajus nigritus & 3 & 0 & 3 & $<25$ \\
\hline \multicolumn{5}{|l|}{ Artiodactila } \\
\hline Mazama gouazoubira & 1 & 1 & 2 & 25 \\
\hline \multicolumn{5}{|l|}{ Marsupialia } \\
\hline Didelphis albiventris & 2 & 0 & 2 & $<25$ \\
\hline \multicolumn{5}{|l|}{ Xenarthra } \\
\hline Tamandua tetradactyla & 3 & 0 & 3 & $<25$ \\
\hline \multicolumn{5}{|l|}{ Rodentia } \\
\hline Hydrochoerus hydrochaeris & 1 & 0 & 1 & $<25$ \\
\hline
\end{tabular}


where they may remain infectious for years (Aston et al., 2013; Carme et al., 2002).

It is important to consider that, in the present study, MAT serologic titers varied between 20 and 120 in birds and between 25 and 1600 in mammals. High titers are generally associated with recent infections. However, in this case, it is not possible to make any conclusions because just one sample was collected and antibody titers can remain high for several months (Dubey, 2010), so single titer values by MAT indicates only exposure to T. gondii.

The validity of serologic tests for T. gondii antibodies in wild birds and wild mammals is not well understood and many variables can be applied such as age, the number of animals studied, and animal species. Validation for MAT is well recognized in chickens (Dubey et al., 2016) and pigs (Dubey, 1997). Nonetheless, MAT is one of the most used serological tests for the diagnosis of toxoplasmosis in humans and other animals, particularly because it requires no conjugates (Dubey, 2010).

Using another serological test, the indirect fluorescent antibody test, Vitaliano et al. (2010) observed that experimentally infected C. plancus had a peak of IgG anti-T. gondii between 15- and 30-days post-inoculation (dpi), with a decreasing or even absence of antibody titers just around 60dpi. This could suggest that negative birds could have been previously exposed to the parasite and confirmation would only be possible by isolating the parasite from their tissues.

\section{References}

Aston EJ, Mayor P, Bowman DD, Mohammed HO, Liotta JL, Kwok O, Dubey JP. Use of filter papers to determine seroprevalence of Toxoplasma gondii among hunted ungulates in remote Peruvian Amazon. Int J Parasitol Parasites Wildl. 2013;3(1):15-9. http://dx.doi.org/10.1016/j. ijppaw.2013.12.001. PMid:24918073.

Carme B, Aznar C, Motard A, Demar M, de Thoisy B. Serologic survey of Toxoplasma gondii in noncarnivorous free-ranging neotropical mammals in french guiana. Vector Borne Zoonotic Dis. 2002;2(1):11-7. http://dx.doi. org/10.1089/153036602760260733. PMid:12656126.

Chen JC, Tsai YJ, Wu YL. Seroprevalence of Toxoplasma gondii antibodies in wild birds in Taiwan. Res Vet Sci. 2015;102:184-8. http://dx.doi.org/10.1016/j.rvsc.2015.08.010. PMid:26412541.

Da Silva RC, Machado GP, Cruvinel TMA, Cruvinel CA, Langoni $\mathrm{H}$. Detection of antibodies to Toxoplasma gondii
The data obtained in the present study show T. gondii infection in several animal species in the northwest region of São Paulo state and indicate the environmental contamination of the area. Studies of this nature may help to understand the importance of the prevention and control of this disease in Brazil.

\section{Conflict of Interest}

The authors declare no conflicts of interest.

\section{Ethics Statement}

All biological material collection herein was authorized for scientific purposes by the Biodiversity Information and Authorization System (SISBIO) from the Brazilian Federal Environmental Agency (IBAMA) under certificate number $43854-4$ and was approved by the Research Ethics Committees at the universities involved in this study (Rio Preto University Center [UNIRP] under authorization number 04/2014PP and São José do Rio Preto Medical School [FAMERP] under authorization number 2014/05302-8).

\section{Acknowledgements}

We thank Dr. J.P. Dubey from the United States Department of Agriculture, Animal Parasitic Diseases Laboratory for kindly providing the Toxoplasma gondii antigen.

in wild animals in Brazil. J Venom Anim Toxins Incl Trop Dis. 2014;20(1):41. http://dx.doi.org/10.1186/1678-919920-41. PMid:25278979.

Dubey JP, Desmonts G. Serological responses of equids fed Toxoplasma gondii oocysts. Equine Vet J. 1987;19(4):3379. http://dx.doi.org/10.1111/j.2042-3306.1987.tb01426.x. PMid:3622463.

Dubey JP, Lago EG, Gennari SM, Su C, Jones JL. Toxoplasmosis in humans and animals in Brazil: high prevalence, high burden of disease, and epidemiology. Parasitology. 2012;139(11):1375-424. http://dx.doi.org/10.1017/ S0031182012000765. PMid:22776427.

Dubey JP, Lappin MR, Thulliez P. Long term antibody responses of cat fed Toxoplasma gondii tissue cysts. J Parasitol. 1995;81(6):887-93. http://dx.doi.org/10.2307/3284035. PMid:8544059. 
Dubey JP, Laurin E, Kwowk OCH. Validation of the modified agglutination test for the detection of Toxoplasma gondii in free-range chickens by using cat and mouse bioassay. Parasitology. 2016;143(3):314-9. http://dx.doi.org/10.1017/ S0031182015001316. PMid:26625933.

Dubey JP. Toxoplasma gondii infections in chickens (Gallus domesticus): prevalence, clinical disease, diagnosis and public health significance. Zoonoses Public Health. 2010;57(1):6073. http://dx.doi.org/10.1111/j.1863-2378.2009.01274.x. PMid:19744305.

Dubey JP. Validation of the specificity of the modified agglutination test for toxoplasmosis in pigs. Vet Parasitol. 1997;71(4):307-10. http://dx.doi.org/10.1016/S03044017(97)00016-2. PMid:9299699.

Fialho CG, Teixeira MC, Araujo FAP. Toxoplasmose animal no Brasil. Acta Sci Vet. 2009;37(1):1-23.

Garcia JL, Svoboda WK, Chryssafidis AL, de Souza Malanski L, Shiozawa MM, de Moraes Aguiar L, Teixeira GM, Ludwig G, Da Silva LR, Hilst C, Navarro IT. Sero-epidemiological survey for toxoplasmosis in wild New World monkeys (Cebus spp.; Alouatta caraya) at the Paraná river basin, Paraná State, Brazil. Vet Parasitol. 2005;133(4):307-11. http:// dx.doi.org/10.1016/j.vetpar.2005.06.004. PMid:16006040.

Gennari SM, Canón-Franco WA, Yai LE, de Souza SL, Santos LC, Farias NA, Ruas J, Rossi FW, Gomes AA. Seroprevalence of Toxoplasma gondii antibodies from wild canids from Brazil. Vet Parasitol. 2004;121(3-4):337-40. http://dx.doi. org/10.1016/j.vetpar.2004.02.023. PMid:15135875.

Gennari SM, Raso TF, Guida FJV, Pena HFJ, Soares HS, Dubey JP. Occurrence of antibodies to Toxoplasma gondii in scavenging black vultures (Coragyps atratus) in Brazil. Braz J Vet Res Na Sci. 2017;54(2):197-9. http://dx.doi. org/10.11606/issn.1678-4456.bjvras.2017.128818.

Gonçalves GAM, Almeida SM, Camossi LG, Langoni H, Andreatti Filho RL. Avaliação sorológica de Parainfluenzavirus Tipo 1, Salmonella spp., Mycoplasma spp. e Toxoplasma gondii em aves silvestres. Cienc Anim Bras. 2013;14(4):47380. http://dx.doi.org/10.5216/cab.v14I4.16576.

Minervino AHH, Soares HS, Barrêto-Júnior RA, Neves KAL, de Jesus Pena HF, Ortolani EL, Dubey JP, Gennari SM. Seroprevalence of Toxoplasma gondii antibodies in captive wild mammals and birds in Brazil. J Zoo Wildl
Med. 2010;41(3):572-4. http://dx.doi.org/10.1638/20100046.1. PMid:20945665.

Oliveira S, Mattos PSR, Mattos KK, Toppa RH, Costa AP, Marcili A, Ferreira JIGS, Krawczak FDS, Labruna MB, Gennari SM, Pena HFJ. Presence of anti-Toxoplasma gondii, -Neospora caninum, -Leishmania spp. and -Ehrlichia canis antibodies in free-ranging maned wolves (Chrysocyon brachyurus) in the northeastern region of the state of São Paulo, Brazil. Braz J Vet Res Anim Sci. 2016;53(3):243. http:// dx.doi.org/10.11606/issn.1678-4456.bjvras.2016.107917.

Rêgo WMF, Costa JGL, Baraviera RCA, Pinto LV, Bessa GL, Lopes REN, Silveira JAG, Vitor RWA. Genetic diversity of Toxoplasma gondii isolates obtained from free-living wild birds rescued in Southeastern Brazil. Int J Parasitol Parasites Wildl. 2018;7(3):432-38. http://dx.doi.org/10.1016/j. ijppaw.2018.11.001.

Vitaliano SN, Mineo TWP, André MR, Machado RZ, Mineo JR, Werther K. Experimental infection of Crested Caracara (Caracara plancus) with Toxoplasma gondii simulating natural conditions. Vet Parasitol. 2010;172(1-2):71-5. http:// dx.doi.org/10.1016/j.vetpar.2010.04.010. PMid:20451327.

Vitaliano SN, Soares HS, Pena HFJ, Dubey JP, Gennari SM. Serologic evidence of Toxoplasma gondii infection in wild birds and mammals from southeast Brazil. J Zoo Wildl Med. 2014;45(1):197-9. http://dx.doi.org/10.1638/20130179R.1. PMid:24712186.

Weiss LM, Dubey JP. Toxoplasmosis: a history of clinical observations. Int J Parasitol. 2009;39(8):895-901. http:// dx.doi.org/10.1016/j.ijpara.2009.02.004. PMid:19217908.

Financial Support: This study was supported by Fundação de Amparo à Pesquisa do Estado de São Paulo (FAPESP \#2015/23605-0 to HSS; \#2013/15879-8 to FHAM; \#2014/05302-8 to LC; \#2014/25872-3 to LPNA); Conselho Nacional de Desenvolvimento Científico e Tecnológico [fellowship to SMG]; and Coordenação de Aperfeiçoamento de Pessoal de Nível Superior (CAPES Scholarship). The opinions, assumptions, and conclusions, or recommendations expressed in this material are the responsibility of the authors and do not necessarily reflect the views of FAPESP. The funders had no role in study design, data collection, and analysis, decision to publish, or preparation of the manuscript. 